\title{
MICROTOOLS BASED ON THE RELATIONAL DATA sciendo MODEL - CONFORMITY BETWEEN FOREIGN AND PRIMARY KEYS
}

doi:10.2478/mape-2018-0062

Date of submission of the article to the Editor: 03/2018 Date of acceptance of the article by the Editor: 06/2018

\author{
MAPE 2018, volume 1, issue 1, pp. 491-497
}

Bartosz Szczęśniak PhD., Eng.

Silesian University of Technology, Poland

\begin{abstract}
Tools which support and automate the execution of information processes may be created in a spreadsheet by following the author's signature concept of "Microtools Based on the Relational Data Model". While developing them, one must apply adequate solutions enabling representation of identified entities and ensuring data integrity as well as acquisition of the reports and collations assumed to be generated. This article addresses the problem of conformity between values of foreign keys in child entities and values of primary keys in parent entities. Four cases of relationships between a parent entity and a child entity have been discussed. One of the criteria that differentiates between these cases is the occurrence of a simple key or a composite key. Another applicable criterion is the sequence in which data are entered using the tool. With regard to all the identified cases, solutions that support data integrity have been presented and discussed. In accordance with the concept in question, the solutions proposed in the paper make use of standard spreadsheet features and components, without involving any additional code created in any programming language.
\end{abstract}

Keywords: spreadsheet, database, business process improvement, information process

\section{INTRODUCTION}

Every contemporary business seeks to ensure appropriate quality of the products or services they deliver (Gajdzik and Sitko, 2014; Midor and Kučera, 2018). The efforts undertaken in this respect may involve determining tendencies and targets for changes of properties and parameters of the goods produced, choice of appropriate materials and semi-finished products, introducing adequate management systems or ensuring quality of the implemented processes, both the manufacturing (Restecka and Wolniak, 2016) and the supporting ones (Loska, 2012; Zasadzień and Midor, 2015; Zasadzień and Žarnovský, 2018). A major component of numerous processes deployed in organisations is information. Processes where information is generated, collected, stored, processed, rendered, interpreted or used are referred to as information processes (Oleński, 2001; 2002). A decided majority of such processes is currently performed using adequate IT tools. Nevertheless, one can still often come across such processes where the actions involving information are executed manually or with a fair share of manual operations. Irrespective of the IT tools the given organisation uses, they are incapable of completely solving all the dynamically changing problems concerning data recording and processing once and for all. Some situations which may trigger new challenges to occur in this respect include emergence of unforeseen issues, a necessity to focus on a specific section of an enterprise in a more detailed manner than before, or implementation of novel and innovative data analysis concepts. Introducing modifications into the IT systems previously deployed often entails the need for involvement of outsourced personnel and, consequently, requires considerable expenses. Implementation of changes itself requires significant amount of time which is usually scarce in organisations. Where this is the case, a good idea for improvement of IT processes is autonomous development of tools that enable automation of the tasks performed. An 
environment in which one can create tools supporting implementation of information processes is that of spreadsheets. They are very popular and available in nearly every organisation. The range of their potential applications, as proposed in the literature of the subject, is extremely broad, including quality management (Knight, 2006; Szczęśniak, 2010; Szczęśniak and Molenda, 2013), management in finance (Jackson and Staunton, 2013; Wilczewski and Wrzód, 2008), sales management or marketing (Carlberg, 2009). Another interesting concept is to use the spreadsheet as a relational database engine (Tyszkiewicz, 2010; Sroka et al., 2015). The Relational Data Model provides grounds for using spreadsheets to create tools which conform with the author's signature concept of Microtools Based on the Relational Data Model, abbreviated to MiRel (Szczęśniak, 2010; 2016). However, the tools thus developed may only function properly if the data they use are consistent. For this very reason, one of the main components of such tools is a set of solutions ensuring integrity of the data stored in them. One of the aspects typically taken into consideration in this respect is the conformity between values of foreign keys in child entities and values of primary keys in parent entities. This publication addresses four solutions that can be applied in four cases identified in this sphere when using entity representation of the $1^{\text {st }}$ type (Szczęśniak, 2017).

\section{SOLUTIONS ENSURING CONFORMITY BETWEEN VALUES OF FOREIGN KEYS AND OF PRIMARY KEYS}

Case one corresponds to a basic arrangement, being also the most frequent one. The migrating primary key of the parent entity is a simple key in this case. As for the values of the corresponding foreign key in the child entity, one may only enter values which have already been entered in the parent entity. A sample arrangement of entities for this case has been illustrated in Figure 1.

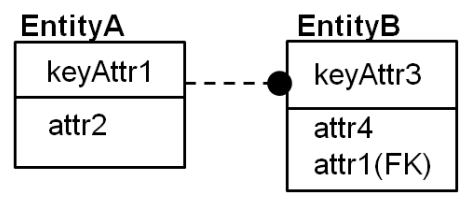

Fig. 1. Arrangement of entities in the first case

In accordance with the MiRel concept, tables representing both entities are placed in separate worksheets. One can ensure conformity between values of the primary and the foreign key by application of the Data Validation mechanism associated with the Name Manager. This solution has been schematically illustrated in Figure 2.

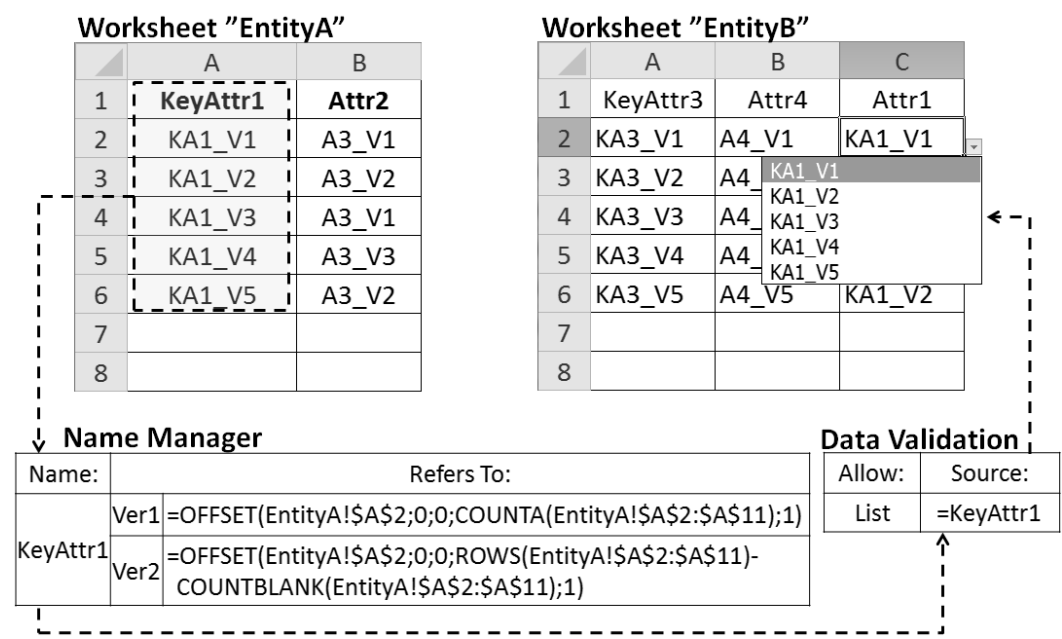

Fig. 2. Schematic diagram of the solution used in the first case 
With such a solution used, attribute "attr1" in entity "EntityB" is entered via a drop-down list containing a set of permissible values. By means of the Data Manager, one can easily create multiple references to a range containing source values scattered all around the tool. The range of cells to which the created name refers must change dynamically, so that it only encompasses cells containing the values previously entered. By that means, the Data Validation feature can actually restrict the values which may be entered, and no empty range appears in the drop-down list. A formula which ensures dynamic addressing has been provided in two variants. Variant "Ver1" is less complex, but it can only be applied under the condition that the "keyAttr1" values in worksheet "EntityA" are entered manually, and empty cells are truly empty. Variant "Ver2" is more extensive, but it can also be used in the event that the "keyAttr1" values are entered by means of a formula, and empty cells contain the "' sign.

Another case taken into consideration is an arrangement where the parent entity's primary key is a composite key. A sample arrangement of entities for this case has been illustrated in Figure 3.

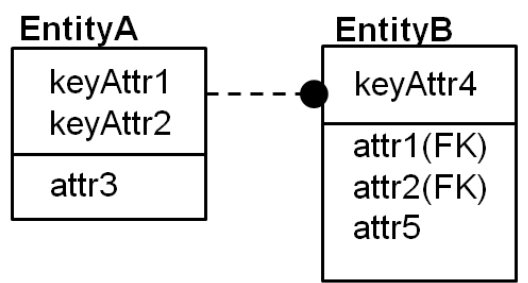

Fig. 3. Arrangement of entities in the second case

Similarly to the first case, with such an arrangement, in order to ensure conformity between the primary key values and those of the foreign key, one may apply a solution that uses the Data Validation feature as well as the Name Manager. Where this is the case, however, it is necessary to ensure that value pairs "attr1-attr2" entered in "EntityB" match pairs "keyAttr1keyAttr2" previously entered in "EntityA". The solution proposed by the author is based on an assumption that values "attr1" and "attr2" are entered at the same time from a drop-down list of permissible values of pairs "attr1-attr2". The values entered as pairs are then separated into values of individual attributes. This solution requires auxiliary columns to be added in both worksheets, i.e. "EntityA" and "EntityB". A schematic diagram of the solution, including the columns added and the formulas applied in them, has been shown in Figure 4.

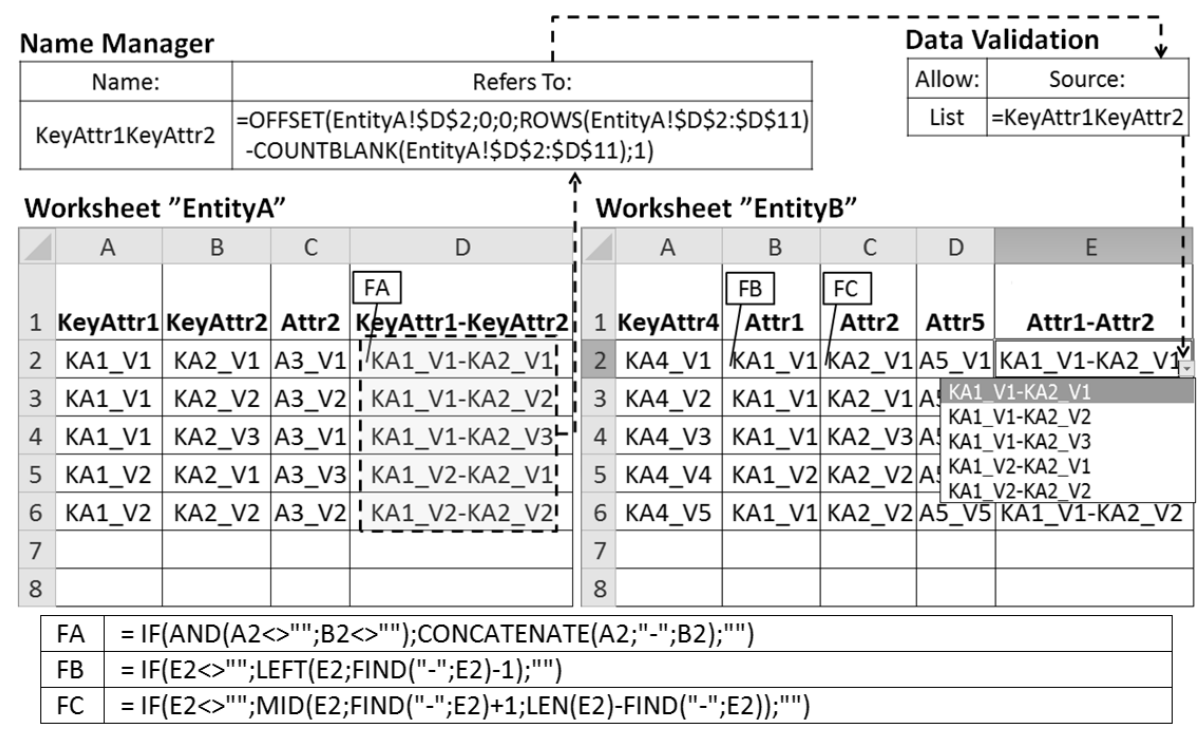

Fig. 4. Schematic diagram of the solution used in the second case 
In column "KeyAttr1-KeyAttr2" of worksheet "EntityA", formula "FA" creates pairs of values of attributes "keyAttr1" and "keyAttr2". The value pairs thus created form the data source for the drop-down list by means of which values are entered in column "Attr1-Attr2" in worksheet "EntityB". They respectively isolate the values of "attr1" and "attr2" from the entered value of formula "FB" and "FC". In the case discussed, it was assumed that values of individual attributes in each pair are separated by the "-" sign. In order for the solution to work properly, one must assume that this sign will not occur in values of attribute "attr1".

In the third of the cases studied, the arrangement of entities is identical to the first case. However, this case pertains to a situation where the values entered as attributes of entity "EntityB" are entered in their entirety, as a copy of a table retrieved from an external source. In such an event, once the values have been copied, values of attribute "attr1" that do not yet exist in the table which represents entity "EntityA" can be entered in the table representing entity "EntityB". This situation is only acceptable directly after the relevant values have been copied, however, the user should immediately enter values of attributes "keyAttr1" so that the attribute values in both entities conform with one another. The solution proposed under this scenario assumes that, in table "EntityB", values of attributes "attr1" that do not have equivalents in table "EntityA" become highlighted. Additionally, the user can enter the missing attributes of "keyAttr1" in table "EntityA" by selecting them from a drop-down list. A schematic diagram of this solution, along with the columns added and the formulas applied in them, has been provided in Figure 5 .

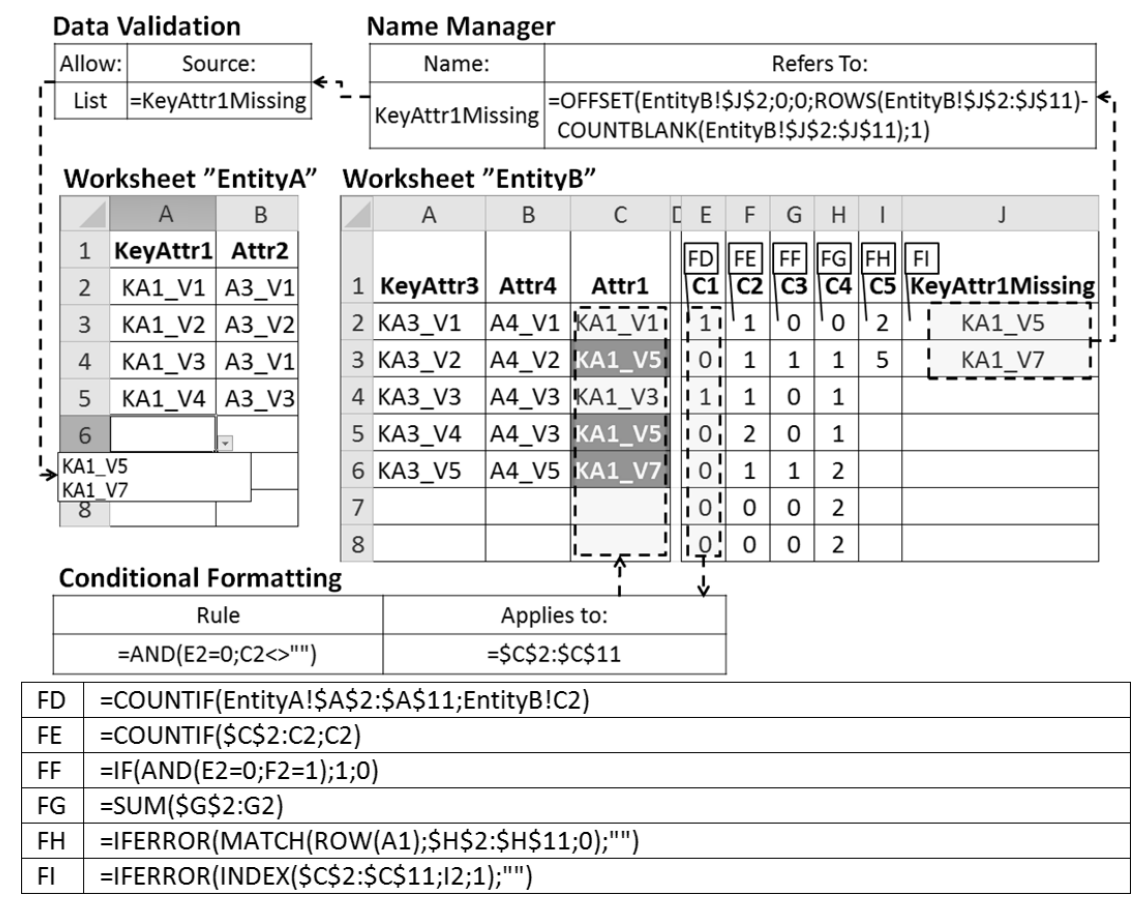

Fig. 5. Schematic diagram of the solution used in the third case

In this solution, 6 auxiliary columns have been added to worksheet "EntityB". As a consequence of the formulas they contain, a collation of attributes "attr1" without equivalents in worksheet "EntityA" is created in column "KeyAttr1Missing". It provides a source of data for the drop-down list which may be used while entering the values of attribute "keyAttr1" in worksheet "EntityA". In this case, the drop-down list is of ancillary nature, as it makes the entry of missing data easier. By no means does it restrict the set of values which can be entered. In order to highlight the relevant values of attribute "attr1" in worksheet "EntityB", the Conditional Formatting feature has been used. The conditional formatting rule applied is based on the values returned by formula "FD". 
The last case studied pertains to a situation where the arrangement of entities corresponds to that shown in Figure 3, with the exception that the sequence in which values are entered into individual tables is reversed, as in case three. This time, pairs of values of attributes "attr1-attr2" that do not have equivalents in pairs of attributes "keyAttr1-keyAttr2" in worksheet "EntityA" may emerge in worksheet "EntityB". According to the solution proposed, these pairs become highlighted in worksheet "EntityB", while in worksheet "EntityA", attributes "keyAttr1" and "KeyAttr2" are entered at the same time as pairs of values selected from a drop-down list of missing value pairs. A diagram schematically illustrating this solution has been provided in Figure 6 .

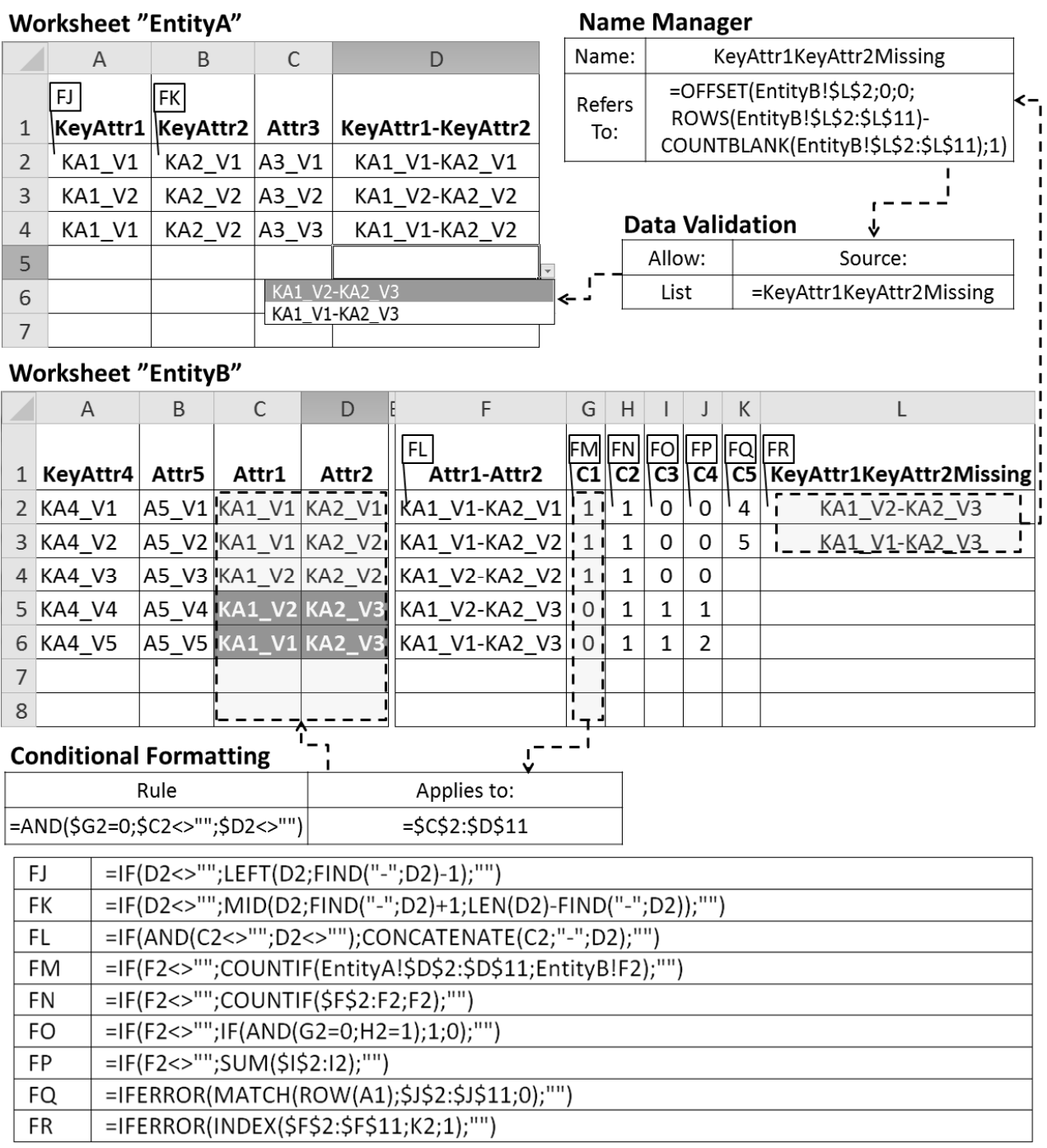

Fig. 6. Schematic diagram of the solution used in the fourth case

In this solution, seven auxiliary columns have been added to worksheet "EntityB". Found in columns "Attr1-Attr2" and "C1", formulas "FL" and "FM" check if the current pair of attributes "attr1-attr2" exists in worksheet "EntityA". The values returned by formula "FM" provide grounds to determine the cells in columns "Att1" and "Attr2" which should become highlighted by means of the Conditional Formatting feature. Making use of the values returned by formulas "FL" and "FM", formulas "FN", "FO", "FP", "FQ" and "FR" create a collation of the missing pairs of values of attributes "attr1-attr2". The missing pairs may be entered in the additional column "KeyAttr1-KeyAttr2" in worksheet "EntityA" by selecting them from the drop-down list. The value pairs thus entered are broken down into the value of 
attribute "keyAttr1" and that of attribute "keyAttr2" as a result of the operations executed by formulas "FJ" and "FK".

\section{CONCLUSIONS}

There are four possible scenarios identified by analysing the problem of ensuring conformity between primary keys in parent entities and foreign keys in child entities in accordance with the concept of Microtools Based on the Relational Data Model, and they correspond to the following cases:

1. A case where there is a simple key, and values are entered in the parent entity in the first instance;

2. A case where there is a composite key, and values are entered in the parent entity in the first instance;

3. A case where there is a simple key, and values are entered in the child entity in the first instance;

4. A case where there is a composite key, and values are entered in the child entity in the first instance.

With reference to each of the identified cases, a supporting solution has been proposed to ensure data integrity. The selection of spreadsheet components and features used in the solutions discussed in the paper is relatively limited, and these are: Conditional Formatting, Name Manager and Data Validation. The formulas created for that purpose are based on such functions as: IF(), OFFSET(), COUNTA(), COUNTBLANK(), ROWS(), AND(), CONCATENATE(), LEFT(), FIND(), LEN(), MID(), COUNTIF(), SUM(), IFERROR(), $\mathrm{MATCH}()$ and INDEX(). The solutions proposed by the author clearly show that the problem of ensuring conformity between primary keys and foreign keys may be rectified by relatively simple means, without resorting to application of a code developed in any programming language.

\section{ACKNOWLEDGEMENTS}

The paper is the result of statutory research carried out at the Institute of Production Engineering at the Faculty of Organization and Management of the Silesian University of Technology as part of a project number 13/030/BK_18/0039 called "Development of intelligent production methods as well as work and life environments in the context of production engineering challenges".

\section{REFERENCES}

Carlberg, C. (2009). Microsoft Excel 2007 PL. Analizy biznesowe. Rozwiązania w biznesie. Wydanie III. Gliwice: Helion.

Gajdzik, B.,Sitko, J. (2014). An analysis of the causes of complaints about steel sheets in metallurgical product quality management systems. Metalurgija, 53(1), pp. 135-138.

Jackson, M., Staunton, M. (2013). Zaawansowane modele finansowe $z$ wykorzystaniem Excela i VBA. Gliwice: Helion.

Knight, G.(2006). Analyzing Business Data with Excel. Sebastopol: O'Reilly Media

Loska, A.,(2012). Remarks about modelling of maintenance processes with the use of scenario techniques. Eksploatacja i Niezawodnosc - Maintenance and Reliability, 14(2), pp. 92-98.

Midor, K., Kučera, M. (2018). Improving the Service with the Servqual Method. Management Systems in Production Engineering, 26(1), pp. 60-65.

Oleński, J. (2001). Ekonomika informacji. Podstawy. Warszawa: PWE.

Oleński, J. (2002). Ekonomika informacji. Metody. Warszawa: PWE.

Restecka, M., Wolniak, R. (2016). IT systems in aid of welding processes quality management in the automotive industry. Archives of Metallurgy and Materials, 61(4), pp. 1785-1792

Sroka, J., Panasiuk, A., Stencel, K., Tyszkiewicz, J. (2015). Translating Relational Queries into Spreadsheets. IEEE Transactions On Knowledge and Data Engineering, 27(8), pp. 2291-2303.

Szczęśniak, B. (2010). Arkusz kalkulacyjny w doskonaleniu procesu układania planu zajęć w szkole specjalnej. In: R. Knosala, ed., Komputerowo zintegrowane zarządzanie, Opole: Oficyna Wydawnicza Polskiego Towarzystwa Zarządzania Produkcją, Opole. 2, pp. 222-233. 
Szczęśniak, B. (2010). Zastosowanie arkusza kalkulacyjnego do wspomagania metody ABC. Zeszyty Naukowe Politechniki Śląskiej, seria Organizacja i Zarządzanie, 50, pp. 23-33.

Szczęśniak, B. (2016). Mikronarzędzia bazujące na relacyjnym modelu danych a rozwój specjalizacji inteligentnych. Systemy Wspomagania w Inżynierii Produkcji -Metody i Narzędzia Inżynierii Produkcji dla Rozwoju Inteligentnych Specjalizacji, 4(16), pp.121-131.

Szczęśniak, B. (2017). Microtools Based on the Relational Data Model - representation of entities in a spreadsheet. In: 17th International Multidisciplinary Scientific GeoConference SGEM 2017. Albena, 17(21), pp. 447-454.

Szczęśniak, B., Molenda, M. (2013). Spreadsheet application supporting the x-r control chart. In: 22th Conference Modern Mathematical Methods in Engineering (3mi). Horní Lomná, pp. 128-134.

Tyszkiewicz, J. (2010). Spreadsheet As a Relational Database Engine, In: ACM SIGMOD International Conference on Management of data, Indianapolis, pp.195-206.

Wilczewski, S., Wrzód, M. (2008). Excel 2007 w firmie. Controlling, finanse i nie tylko. Gliwice: Helion.

Winston, W. L. (2011). Microsoft Excel 2010. Data Analysis and Business Modeling. Third Edition. Washington: Microsoft Press.

Zasadzień, M., Midor, K. (2015). Innovative application of quality management tools in a hard coal mine. In: 15th International Multidisciplinary Scientific GeoConference SGEM 2015. Albena, 1(3), pp. 415-422.

Zasadzień, M., Žarnovský, J. (2018). Improvement of Selected Logistics Processes Using Quality Engineering Tools. Management Systems in Production Engineering, 26(1), pp. 55-59. 